whole valley floor, not merely the river, is the barrier. The other important result of the periglacial elimate is that it leads to the formation of vast sheets of loess spread over the country as a blanket. On the slopes this has been largely removed, but on the plateau areas it still exists. Its effects are numerous. On the loess soil the type of agriculture is plough lands with large open fields without hedges. The silty nature of the soil renders it firm and quickdrying during summer but highly treacherous in winter and spring. It is on such plateau lands during the summer months that airstrips for servicing fighter aircraft could be prepared with least work and where the open country was particularly well suited for rapidly moving armies.

The effects in the coastal regions of movements of the strand line were important. Along all the Channel coasts it was known that peats and clays of the 'Submerged Forest' existed in patches. The location of patches of these under the sands of the Normandy beaches necessitated extremely intensive study, for unless covered by a sufficient thickness of sand, vehicles were liable to become bogged. The work done by Prof. F. W. Shotton and others on this problem was well justified by the results.

It is seen, therefore, that the solid geology of the area controls the broader problems of strategy, while the features resulting from the periglacial position during the Ice Age has had two effects which have been of the greatest importance in controlling details. These are the infilling of the overdeepened valleys with unconsolidated alluvium, rendering them effective barriers, and the presence of the loess-covered plateaux which form large areas suitable for 'open' warfare and give rise to numerous tracts which can be turned rapidly into temporary airstrips for tho landing and servicing of fighter aircraft, a feature of the greatest importance for modern armies.

\section{ORGANIC DESIGN}

T his presidential address to Section $D$ (Zoology), Dr. C. F. A. Pantin remarks that by the beginning of the nineteenth century two principles had emerged from the study of comparative anatomy : first, that structures are adapted to the function which they serve; secondly, that some plan underlies the architecture of whole groups of animals. Purposive adaptation was used as an argument for Divine design. So also was the existence of an underlying anatomical plan. This plan showed two features. First, animals exhibited grades of organization which we term 'higher' and 'lower'. This was partly the old anthropomorphic over-simplification that placed man at the head of a Scala Naturce. The error still persists because it contains an element of truth. 'Higher' animals show functional differentiation which leads to increased independence of the environment. The price of this independence is centralized control, particularly by a brain.

The second feature is that animal organization is found to be based on one or other of a series of architectural types, such as the vertebrate, the molluscan and so on. One hundred years ago, Richard Owen gave precise definition to this idea in his conception of the archetype, which he considered as the expression of an underlying abstract plan-in much the same way as to-day we may consider the groups of the elements of the Periodic Table give expression to such a plan.
The "Origin of Species" gave a totally new interpretation of these things. The type and its structural homologies were consequences of evolution from a common ancestor. Purposive adaptation was the negative image of natural selection.

By 1918 abstract comparative anatomy, even in evolutionary guise, had lost much of its power to inspire research. Many new lines of work opened, particularly in the physiology of animals and their tissues. Almost all these lines have led back to morphology, though from a very different point of view from that of the older comparative anatomists. New relationships emerged at the molecular level of structure. Biochemical similarities appeared between organisms which were utterly sundered in their evolution, as in the carbohydrate metabolism of fermenting yeast and of contracting muscle in vertebrates. Such similarities arise independently because the materials available for the construction of organisms are of few kinds and of unique properties. Consequently the same materials, and these alone, are available again and again for the construction of functional systems independently in different sorts of organism.

Once these limitations are introduced at the molecular level, they affect all higher levels of structure. One of the most remarkable features of comparative physiology is the repeated and independent utilization of the same kind of machinery for muscular movement in quite different animals.

As in the structures erected by engineers, so in the organism, there are three factors governing design : first, any functional problem can only be solved in a limited number of ways; secondly, for any solution only materials of limited kinds and properties are available; thirdly, the engineer selects a solution which he can execute with the materials available. In the same way we may say of living organisms that natural selection gives reality to one or other of a series of possible structural solutions limited by the properties of matter and energy.

As a result of these limitations, we repeatedly find the same structural solution of a functional problem achieved by quite unrelated organisms. The most striking example of this is the independent development of similar nervous machines by which organisms execute their behaviour.

\section{THE CENTENARY OF SECTION E (GEOGRAPHY)}

$\mathrm{T}$ HE year 1951 marks the centenary of Section $\mathrm{E}$ (Geography) in the British Association, and its president, Dr. O. J. R. Howarth, surveys its history and achievements. The subject was previously subordinated to geology, and for some years was confined to physical geography. The establishment of the new section, in which ethnography was at first included, was due to Sir Roderick Murchison. He helped to found the British Association and also the Royal Geographical Society: he was to become a general secretary and afterwards president of the Association, and he maintained an intimate interest in the new Section, assuming its annual presidency no less than seven times. His first conception of its main function was that it should deal with travel, and should attract the interest of lay members of the Association by bringing before them 